Huggins $^{10}$, who has further suggested that the androgen threshold of the prostate may decrease with old age. It has also been reported ${ }^{11}$ that significant improvement often follows castration of patients with advanced cancer of the prostate. The preliminary data here presented appear to indicate that a vitamin antagonist can interfere with the stimulation of a target organ by testosterone, and so reduce the growth response of the male sex accessories to high doses of male sex hormone. These facts may point the way for the utilization of suitable anti-metabolites as a suitable control measure for prostatic hypertrophy. They are, therefore, offered at this stage so that they may be extended to other forms and further tested. Investigations involving chemically pure folic acid analogues and attempts at reversal with synthetic folic acid are in progress in our laboratories.

This investigation was aided by a grant from the National Cancer Institute, National Institute of Health, U.S. Public Health Service.

E. D. GoLDSMith

HERMAN M. BLACK

Ross F. NrGRELII

Department of Histology, College of Dentistry,

New York University, and New York Aquarium,

New York Zoological Society.

${ }^{1}$ Hertz, R., Endocrin., 37, 1 (1945).

'Kline, I. T., and Dorfman, R. I., J. Clin. Endocrin., 8, 602 (1948).

${ }^{3}$ Hertz, R., Proc. Soc. Exp. Biol. and Med., 67, 113 (1948).

${ }^{4}$ Hertz, R., Science, 107, 300 (1948).

${ }^{5}$ Franklin, A. L., Lewis, D., Stokstad, E. L. R., and Jukes, T. H., 37th Annual Meeting, Poultry Science Association, Poultry Sci., 27,662 (1948).

- Hertz, R. (in the press, personal communication).

"Goldsmith, E. D., Schreiber, S. S., and Nigrelli, R. F., Proc. Soc. Exp. Biol. and Med., 69, 299 (1948).

${ }^{8}$ Bittner, J. J., "Biology of the Laboratory Mouse", 321 (edited by G. D. Snell, Blakiston, 1941).

${ }^{9}$ Franklin, A. L., Stokstad, E. L. R., and Jukes, T. H., Proc. Soc. Exp. Biol. and Med., 65, 368 (1947).

${ }^{10}$ Huggins, C., Physiol. Rev., 25, 281 (1945).

${ }^{11}$ Huggins. C., Stevens, R. E., Jun., and Hodges, C. V., Arch. Surg., 43, 209 (1941).

\section{Effect of Thiouracil and Uracil on the Germination of Cress Seeds}

IT has been found that cress seeds sown on a medium containing 2-thiouracil do not germinate normally. If the seeds are sown on a medium containing both thiouracil and uracil, or are pre-treated with uracil before sowing on thiouracil, germination is virtually normal.

Commercial cress seeds have been used in these experiments. They were sown on single layers of lint in Petri dishes, and incubated at $20-22^{\circ} \mathrm{C}$. When the lint was soaked in distilled water, 80-95 per cent of the seeds germinated after seven days incubation. For the purposes of these experiments, germination was considered to have occurred if the cotyledons had expanded.

In a series of experiments, in which the lint was soaked in different concentrations of thiouracil, the results were as follows:

\begin{tabular}{|c|c|c|c|}
\hline $\begin{array}{l}\text { Concentration of } \\
\text { thiouracil }\end{array}$ & $\begin{array}{c}\text { No, of } \\
\text { seeds sown }\end{array}$ & $\begin{array}{l}\text { No. } \\
\text { germinated }\end{array}$ & $\begin{array}{c}\text { Per cent } \\
\text { germinated }\end{array}$ \\
\hline $\begin{array}{ll}0 \cdot 00001 & M \\
0 \cdot 00002 & M \\
0 \cdot 00005 & M \\
0 \cdot 0001 & M \\
0 \cdot 001 & M \\
0 \cdot 01 & M\end{array}$ & $\begin{array}{l}40 \\
40 \\
40 \\
40 \\
40 \\
40\end{array}$ & $\begin{array}{r}32 \\
32 \\
19 \\
6 \\
3 \\
1\end{array}$ & $\begin{array}{l}80 \\
80 \\
48 \\
15 \\
7 \cdot 5 \\
2 \cdot 5\end{array}$ \\
\hline
\end{tabular}

It will be seen that the inhibitory effect of thiouracil first appears at a concentration of $0.00005 M$. In ten trials on separate occasions, the proportion germinating on $0.0001 M$ thiouracil has varied between 2.5 and 15 per cent. Even in the highest concentration the inhibition is not absolute. In most seeds the radicle is just visible after seven days on this concentration of thiouracil, but only occasional seeds progress any further.

Uracil by itself had no apparent effect on the germination of cress seeds at concentrations between 0.0001 and $0.01 M$. But when seeds were sown on a suitable mixture of uracil and thiouracil, the inhibitory effect of the latter was greatly diminished. The results obtained with a fixed concentration of thiouracil, and varying concentrations of uracil, are shown below :

\begin{tabular}{|c|c|c|c|c|}
\hline $\begin{array}{l}\text { Concentration } \\
\text { of thiouracil }\end{array}$ & $\begin{array}{l}\text { Concentration } \\
\text { of uracil }\end{array}$ & $\begin{array}{c}\text { No. of } \\
\text { seeds sown }\end{array}$ & $\begin{array}{l}\text { No. } \\
\text { germinated }\end{array}$ & $\begin{array}{l}\text { Per cent } \\
\text { germinated }\end{array}$ \\
\hline $\begin{array}{l}0 \cdot 0001 M \\
0 \cdot 0001 M \\
0 \cdot 0001 M \\
0 \cdot 0001 M \\
0 \cdot 0001 M \\
0 \cdot 0001 M\end{array}$ & $\begin{array}{ll}0.00001 & M \\
0 \cdot 0001 & M \\
0.001 & M \\
0.002 & M \\
0.01 & M\end{array}$ & $\begin{array}{l}40 \\
40 \\
40 \\
40 \\
40 \\
40\end{array}$ & $\begin{array}{r}4 \\
6 \\
11 \\
27 \\
30 \\
30\end{array}$ & $\begin{array}{l}10 \\
15 \\
28 \\
67 \\
75 \\
75\end{array}$ \\
\hline
\end{tabular}

It will be seen that uracil had to be present in a twenty times greater concentration in order to reverse the effect of thiouracil. Even then the proportion of seeds germinating was not quite so high as on control plates. The seedlings which germinated in the uracil-thiouracil mixture appeared quite normal.

Pre-treatment with a high concentration of uracil is even more effective in enabling seeds to germinate on thiouracil. When seeds were soaked for four hours in $0.01 M$ uracil, and then sown on $0.0001 M$ thiouracil, 82-85 per cent germinated. Successful germination took place even if the seeds were airdried after the four hours soaking in uracil, and sown on thiouracil twenty-four hours later.

Uracil is known to be required for the growth of some bacteria ${ }^{1,2}$ and fungi ${ }^{3}$. It would not be surprising if uracil (or a related pyrimidine) were also required for the germination of the seeds of higher plants. If this is so, then thiouracil might block the action of uracil by reason of the similarity of its molecular structure. This type of reaction was suggested by Strandskov and Wyss, who found that thiouracil inhibited the growth of $E$. coli and $L$. casei, and that the inhibition was reversed by equal or smaller concentrations of uracil.

Medical Unit,

W. R. TrotTter

University College Hospital Medical School, London, W.C.I. Feb. 1 .

${ }^{1}$ Richardson, G. M., Biochem. J., 30, 2184 (1936).

${ }^{2}$ Feeney, R. E., Mueller, J. H., and Miller, P. A., J. Bact., 46, 563 (1943)

${ }^{3}$ Loring, H. S., and Pierce, J. G., J. Biol. Chem., 153, 61 (1944)

${ }^{4}$ Strandskov, F. B., and Wyss, O., $J$ Bact., 50, 237 (1945).

\section{A Diffusible Substance in Irradiated Tissues?}

IN a series of experiments carried out on volunteers, a dose of $\mathrm{X}$-rays was given to two small areas of skin separated by a varying width of untreated protected skin, and the reactions produced were significantly bigger than that over a single area of skin exposed to the same dose of radiation. When, however, the separation between the two paired areas was greater than 